\title{
HUBUNGAN PENGETAHUAN TENTANG KARIES GIGI DENGAN JENIS KARIES GIGI PADA MAHASISWA TINGKAT I DAN II JURUSAN KEPERAWATAN GIGI POLTEKKES KEMENKES MANADO
}

\author{
Anneke Tahulending ${ }^{1}$, Jeineke Ratuela ${ }^{2}$, Sania Natasia Sarah Kembuan ${ }^{3}$ \\ 1,2,3)Jurusan Keperawatan Gigi Poltekkes Kemenkes Manado jl.RW Monginsidi Malalayang Manado \\ Email : anneketahulending@gmail.com
}

\begin{abstract}
ABSTRAK
Pendahuluan:. Pengetahuan yang hanya sekedar diketahui saja tanpa didasari dengan pendidikan yang memadai maka akan berpengaruh terhadap kemauan untuk menjaga dan memelihara kebersihan gigi dan mulutnya. Karies gigi adalah penyakit jaringan gigi yang ditandai dengan kerusakan jaringan, dimulai dari permukaan gigi (pit, fissur, dan daerah interproximal) meluas ke arah pulpa. Tujuan penelitian ini adalah untuk mengetahui Hubungan Pengetahuan Tentang Karies Gigi Dengan Jenis Karies Gigi. Metode: Penelitian ini menggunakan metode deskriptif analitik dengan cross sectional study yaitu mencari hubungan antara variabel. Penelitian ini dilaksanakan pada bulan Mei 2019 dan berlokasi di Jurusan Keperawatan Gigi Poltekkes Kemenkes Manado. Jumlah populasi sebanyak 97 orang, sampel dalam penelitian ini menggunakan tabel penentuan jumlah sampel yang dikembangkan dari Isaac dan Michael untuk tingkat kesalahan yang digunakan 5\% (Sugiyono,2009). Pengambilan sampel ditentukan kriteria inklusi dan eksklusi. Sehingga sampel yang didapat dalam penelitian ini berjumlah 75 responden. Data yang diperoleh ditabulasi dan dianalisis menggunakan uji statistik Chi-Square. Instrument dalam penelitian ini menggunakan kuesioner untuk mengukur pengetahuan mahasiswa tentang karies gigi dan untuk pemeriksaan jenis karies gigi menggunakan alat diagnosa dan format pemeriksaan jenis karies gigi. Hasil: Hasil uji statistik Chi-Square menunjukkan bahwa $r$ hitung lebih besar dari $r$ tabel $(11,279>3,841)$ dengan menggunakan tingkat kepercayaan 0,05 (95\%) diperoleh nilai $\mathrm{p}=0,002 \quad(0,002<0,05)$, sehingga dapat disimpulkan dari hasil yang didapat bahwa ada hubungan yang bermakna antara pengetahuan tentang karies gigi dengan jenis karies gigi pada mahasiswa.
\end{abstract}

\section{Kata Kunci : Pengetahuan Karies Gigi, Jenis Karies Gigi}

\section{ABSTRACT}

Introduction: Knowledge that is only known without being based on adequate education will affect the willingness to maintain and maintain the cleanliness of teeth and mouth. Dental caries is a dental tissue disease characterized by tissue damage, starting from the tooth surface (pits, fissures, and interproximal areas) extending towards the pulp. The purpose of this study was to determine the relationship between knowledge about dental caries and types of dental caries. Methods: This study used a descriptive analytic method with a cross sectional study, namely looking for the relationship between variables. This research was conducted in May 2019 and is located in the Department of Dental Nursing, Ministry of Health, Manado Health Polytechnic. The total population is 97 people, the sample in this study uses a table to determine the number of samples developed from Isaac and Michael for the error rate used is 5\%. Sampling was determined inclusion and exclusion criteria. So that the sample obtained in this study amounted to 75 respondents. The data obtained were tabulated and analyzed using the Chi-Square statistical test. The instrument in this study used a questionnaire to measure students' knowledge about dental caries and to check the type of dental caries using a diagnostic tool and a format for examining the type of dental caries. Results: The results of the Chi-Square statistical test show that $r$ count is greater than $r$ table (11.279> $3.841)$ using a confidence level of $0.05(95 \%)$, the value of $p=0.002(0.002<0.05)$ is obtained, so it can be 
concluded from The results showed that there was a significant relationship between knowledge of dental caries and types of dental caries among students.

Keywords: Knowledge of Dental Caries, Types of Dental Caries

\section{PENDAHULUAN}

Perilaku kesehatan gigi meliputi pengetahuan, sikap, dan tindakan yang berkaitan dengan konsep sehat dan sakit gigi serta upaya pencegahannya. Dalam konsep ini yang dimaksudkan dengan kesehatan gigi adalah gigi dan semua jaringan yang ada di dalam mulut, termasuk gusi. Seseorang memperoleh pengetahuan melalui penginderaan terhadap objek tertentu. Pengetahuan diperoleh sebagai akibat stimulus yang ditangkap pancaindera. Pengetahuan bisa diperoleh secara alami maupun secara terencana yaitu melalui proses pendidikan. ${ }^{1}$

Pendidikan kesehatan berupaya agar masyarakat menyadari atau menguasai bagaimana cara memelihara kesehatan, menghindari, atau mencegah hal-hal yang merugikan kesehatan mereka dan kesehatan orang lain, kemana seharusnya mencari pengobatan jika mereka sakit dan sebagainya. ${ }^{2}$ Kesehatan gigi dan mulut penting bagi kesehatan dan kesejahteraan tubuh secara umum dan sangat mempengaruhi kualitas kehidupan, termasuk fungsi bicara, pengunyahan, dan rasa percaya diri. Di Indonesia, penyakit gigi dan mulut terutama karies dan penyakit periodontal, masih banyak diderita baik oleh anak- anak maupun usia dewasa. ${ }^{3}$

Karies gigi adalah penyakit jaringan gigi yang ditandai dengan kerusakan jaringan, dimulai dari permukaan gigi (pit, fissure, dan daerah interproximal) meluas ke arah pulpa. Karies adalah hasil interaksi dari bakteri di permukaan gigi. Plak atau biofilm, dan diet (khusunya komponen karbohidrat yang dapat difermentasikan oleh bakteri plak menjadi asam terutama asam latat dan asetat) sehingga demineralisasi jaringan keras gigi dan memerlukan cukup waktu untuk kejadiannya ${ }^{4}$

Hasil Riset Kesehatan Dasar (RISKESDAS) tahun 2013 menunjukkan kecenderungan prevalensi penduduk bermasalah gigi dan mulut di Indonesia mencapai 25,9\% dan terjadi peningkatan pada tahun 2018 mencapai $57,6 \%$ penduduk yang bermasalah gigi dan mulut. Di Sulawesi Utara penduduk yang bermasalah gigi dan mulut pada tahun 2013 mencapai 31,6\% dan mengalami peningkatan pada tahun 2018 mencapai $55,5 \% .^{5}$

Berdasarkan survei awal yang di lakukan tanggal 26 April 2019 pada mahasiswa tingkat I dan II Jurusan Keperawatan Gigi Poltekkes Kemenkes Manado,dari 12 orang yang diperiksa didapatkan6 orang dengan jenis karies Profunda, 4 orang dengan jenis karies Profunda dan Media dan 2 orang dengan jenis karies Profunda, Media dan Superfisialis. Dan dari hasil wawancara pada 12 mahasiswa diketahui bahwa mahasiswa memiliki pengetahuan tentang karies gigi yang cukup baik.

Hasil penelitian dari Rahtyanti dkk, (2018) didapati distribusi pengetahuan kesehatan gigi dan mulut Mahasiswa baru Fakultas Kedokteran Gigi Universitas Jember tahun akademik 2016/2017 paling banyak berada pada kategori baik yaitu sebanyak 106 (89,1\%). Dari hasil analisa data menggunakan uji korelasi Spearman hasilnya adalah terdapat hubungan yang signifikan karies gigi dengan pengetahuan kesehatan gigi dan mulut mahasiswa baru Fakultas Kedokteran Gigi Universitas Jember tahun akademik 2016/2017 dengan kekuatan korelasi sedang $(-0,460){ }^{6}$

Tujuan penelitian ini untuk mengetahui hubungan pengetahuan tentang karies gigi dengan 
jenis karies gigi pada mahasiswa tingkat I dan II Jurusan Keperawatan Gigi Poltekkes Kemenkes Manado.

\section{METODOLOGI}

Jenis penelitian ini bersifat analitik dengan studi cross sectional. Jenis penelitian ini berusaha mempelajari dinamika hubungan atau korelasi antara faktor-faktor risiko dengan dampak atau efeknya. Setiap subyek penelitian diobservasi hanya satu kali saja dan fakstor risiko serta dampak diukur menurut keadaan atau status pada saat observasi. ${ }^{1}$

Waktu penelitian dilakukan pada minggu ke III bulan Mei 2019 Tempat penelitian di Jurusan Keperawatan Gigi Poltekkes Kemenkes Manado

\section{Definisi Operasional}

1. Pengetahuan tentang karies gigi adalah hal yang diketahui mahasiswa tentang karies gigi, penyebab karies gigi, proses terjadinya karies, dan akibat karies gigi yang didapatnya secara belajar formal dikelas ataupun melalui media yang dilihat dan didengar. Untuk mengukur pengetahuan mahasiswa tentang karies gigi dengan menggunakan kuesionerterstruktur yang terdiri dari 15 pertanyaan dengan menggunakan 2 alternatif jawaban yaitu "Ya" dan "Tidak". Jika jawaban "Ya" diberi nilai 2 (dua) dan "Tidak" diberi nilai 1 (satu). Hasil nilai pengukuran pengetahuan mahasiswa dikategorikan menjadi dua yaitu "Baik" dan "Kurang Baik". Nilai pengetahuan menggunakan metode yang di buat Maggie C.Y. Tam yaitu metode Natural Cut off point (skor tertinggi+skor terendah:2), jika nilai $\geq 23$ pengetahuan baik kategori 1, nilai $<23$ pengetahuan kurang baik kategori 2. Skala pengukuran nominal. ${ }^{7}$

2. Jenis Karies adalah suatu kerusakan gigi yang dirasakan atau diderita mahasiswa berdasarkan tingkat keparahannya yang dimulai dari lapisan email, dentin sampai pulpa dan dari keluhan yang ringan, sedang sampai berat. Untuk mengukur jenis karies dengan menggunakan 3 cara pemeriksaan yaitu inspeksi, sondase dan thermis, kemudian hasilnya dicatat pada format pemeriksaan. Hasil ukur "Jenis Karies" yaitu tidak ada karies diberi nilai “0”, karies Profunda (Vital dan Non Vital) diberi nilai "1", karies Media diberi nilai " 2 " dan karies Superfisialis diberi nilai " 3 ". Pemeriksaan ini hanya mencari jenis kariesnya saja, bukan jumlah kariesnya.Nilai jenis karies gigi menggunakan metode yang di buat Maggie C.Y. Tam yaitu metode Natural Cut off point (skor tertinggi+skor terendah:2), jika $\geq 3$ kriteria jenis karies gigi baik kategori 1, jika $<3$ kriteria jenis karies gigi kurang baik kategori 2. Skala pengukuran nominal. $^{7}$

Populasi dalam penelitian ini yaitu mahasiswa tingkat I dan II Jurusan Keperawatan Gigi Poltekkes Kemenkes Manado tahun akademik 2019/2020 yang berjumlah 97 orang. Teknik pengambilan sampel dalam penelitian ini menggunakan tabel penentuan jumlah sampel yang dikembangkan dari Isaac dan Michael untuk tingkat kesalahan yang digunakan $5 \% .^{8}$ Semua subjek yang memenuhi kriteria penilaian yaitu mahasiswa tingkat I dan II Jurusan Keperawatan Gigi Poltekkes Kemenkes Manado tahun akademik 2019/2020. Agar pengambilan sampel tepat, maka sebelum pengambilan sampel perlu ditentukan kriteria inklusi dan ekslusi. Sehingga sampel yang didapat dalam penelitian ini berjumlah 75 responden.

\section{HASIL}

Jurusan Kesehatan Gigi Politeknik Kesehatan Kemenkes Manado yang terletak di kampus A Jalan R.W. Monginsidi Kelurahan Malalayang II Barat Kecamatan Malalayang pada awalnya adalah gedung dari Sekolah Pengatur Rawat Gigi Manado yang sudah ditempati sejak tahun 1994. Pada tahun 2002 dikonservasi dari Jenjang 
pendidikan Menengah menjadi Jenjang Pendidikan Tinggi dan pada tahun tersebut diadakan penerimaan mahasiswa baru untuk pendidikan Diploma III yang pada saat menjadi Akademi kesehtan Gigi. Tahun 2004 bergabung dengan Politeknik Kesehatan Manado menjadi Program Studi Kesehatan Gigi dibawah naungan Jurusan Keperawatan. Tahun 2006 dari Program Studi Kesehatan Gigi Politeknik Kesehatan Manado menjadi Jurusan Kesehatan Gigi. Bulan Mei 2011 nomenklatur Jurusan Kesehatan Gigi berubah menjadi Jurusan Keperawatan Gigi, dan berdasarakan SK Menristek Dikti nomor 596/KPT/I/2019 tanggal 18 Juli 2019 tentang perubahan nama Jurusan Keperawatan Gigi menjadi Jurusan Kesehatan Gigi sampai dengan sekarang.

\section{Distribusi Responden Berdasarkan Kategori Pengetahuan}

Distribusi responden berdasarkan kategori pengetahuan tentang karies gigi dapat dilihat pada tabel 1 .

Tabel 1. Distribusi Responden Berdasarkan Kategori Pengetahuan

\begin{tabular}{ccc}
\hline $\begin{array}{c}\text { Kategori } \\
\text { Pengetahuan }\end{array}$ & Jumlah & Persentase (\%) \\
\hline Baik & 64 & 85.3 \\
Kurang baik & 11 & 14.7 \\
\hline Total & 75 & 100 \\
\hline
\end{tabular}

Data pada tabel 1 menunjukkan bahwa responden dengan pengetahuan tentang karies gigi kategori "Baik" sebanyak 64 responden $(85,3 \%)$ dan kategori "Kurang Baik" sebanyak 11 responden $(14,7 \%)$.

\section{Distribusi Responden Berdasarkan Jenis Karies Gigi}

Distribusi responden berdasarkan jenis karies gigi dapat dilihat pada tabel 2 berikut ini
Tabel 2. Distribusi Responden Berdasarkan Jenis Karies Gigi

\begin{tabular}{lcc}
\hline Jenis Karies Gigi & Jumlah & $\begin{array}{l}\text { Persentase } \\
(\mathbf{\%})\end{array}$ \\
\hline Karies Superfisialis & 32 & 42.7 \\
Karies Media & 38 & 50.7 \\
Karies Profunda & 52 & 69.3 \\
\hline Total & $\mathbf{7 5}$ & $\mathbf{1 0 0}$ \\
\hline
\end{tabular}

Data pada tabel 2 menunjukkan bahwa Karies Superfisialis sebanyak 32 jenis karies gigi $(42,7 \%)$, Karies Media sebanyak 38 jenis karies gigi $(50,7 \%)$, dan Karies Profunda sebanyak 52 jenis karies gigi $(69,3 \%)$.

\section{Distribusi Responden Berdasarkan Kategori Jenis Karies Gigi}

Distribusi responden berdasarkan kategori jenis karies gigi dapat dilihat pada tabel 3 .

Tabel 3. Distribusi Responden Berdasarkan Kategori Jenis Karies Gigi

\begin{tabular}{lcc}
\hline $\begin{array}{c}\text { Kategori Jenis } \\
\text { Karies }\end{array}$ & Jumlah & $\begin{array}{c}\text { Persentase } \\
(\boldsymbol{\%})\end{array}$ \\
\hline Baik & 40 & 53.3 \\
Kurang Baik & 35 & 46.7 \\
\hline Total & $\mathbf{7 5}$ & $\mathbf{1 0 0}$ \\
\hline
\end{tabular}

Data pada tabel 3 menunjukkan bahwa responden dengan jenis karies gigi kategori "Baik" yaitu sebanyak 40 responden $(53,3 \%)$, dan kategori “ Kurang Baik" yaitu sebanyak 35 responden $(46,7 \%)$.

\section{Distribusi Responden Berdasarkan Kategori Pengetahuan Dengan Jenis Karies Gigi}

Distribusi responden menurut kategori pengetahuan dengan kategori jenis karies gigi dapat dilihat pada tabel 4 . 
Tabel 4. Distribusi Frekuensi Menurut Kategori Pengetahuan Dengan Kategori Jenis Karies Gigi

\begin{tabular}{|c|c|c|c|c|c|c|}
\hline \multirow{2}{*}{$\begin{array}{c}\text { Kategori } \\
\text { Pengetahua } \\
\mathrm{n} \\
\end{array}$} & \multicolumn{4}{|c|}{ Kategori Jenis Karies } & \multirow[b]{2}{*}{$\begin{array}{c}\text { Jumla } \\
\mathrm{h}\end{array}$} & \multirow[b]{2}{*}{$\begin{array}{c}\text { Persentas } \\
\text { e }(\%)\end{array}$} \\
\hline & $\begin{array}{l}\text { Bai } \\
\mathrm{k}\end{array}$ & $\%$ & $\begin{array}{l}\text { Kuran } \\
\text { g Baik }\end{array}$ & $\%$ & & \\
\hline Baik & 29 & $\begin{array}{c}38 . \\
7\end{array}$ & 35 & $\begin{array}{c}46 . \\
6\end{array}$ & 64 & 85.3 \\
\hline $\begin{array}{l}\text { Kurang } \\
\text { Baik }\end{array}$ & 11 & $\begin{array}{c}14 . \\
7\end{array}$ & 0 & 0 & 11 & 14.7 \\
\hline Total & 40 & $\begin{array}{c}53 . \\
4 \\
\end{array}$ & 35 & $\begin{array}{c}46 . \\
6\end{array}$ & 75 & 100 \\
\hline
\end{tabular}

Data dari tabel 4 menunjukkan bahwa responden dengan pengetahuan kategori "Baik" dengan jenis karies gigi kategori "Baik" sebanyak 29 responden $(38,7 \%)$, pengetahuan kategori "Baik" dengan jenis karies gigi kategori "Kurang Baik" sebanyak 35 responden (46,6\%), pengetahuan kategori "Kurang Baik" dengan jenis karies gigi kategori "Baik" sebanyak 11 responden (14,7\%). Dan pengetahuan kategori "Kurang Baik" dengan jenis karies gigi kategori "Kurang Baik" sebanyak 0.

\section{Pengetahuan Tentang Karies Gigi Dengan Jenis Karies Gigi Hasil Analisis Uji Statistik Chi-Square}

Hasil uji statistk Chi-Square hubungan pengetahuan tentang karies gigi dengan jenis karies gigi dengan taraf signifikasi 0,05 dapat dilihat pada tabel 5 .

Tabel 5. Hasil Uji Statistik Chi-Square

\begin{tabular}{ccccc}
\hline Variable & $\left(\chi^{2}\right)$ tabel & $\left(\chi^{2}\right)$ hitung & $\alpha$-Alpha & Sig \\
\hline $\begin{array}{c}\text { Pengetahuan } \\
\text { Jenis Karies } \\
\text { Gigi }\end{array}$ & 3,841 & 11,279 & 0,05 & 0,002 \\
\hline
\end{tabular}

Hasil uji statistik Chi-Square pada tabel 5. Dengan menggunakan Sofware computer Statistik , menunjukkan bahwa Chi-Square hitung lebih besar dari Chi- Square tabel (11,279>3,841) dengan menggunakan tingkat kepercayaan 0,05 (95\%) diperoleh nilai $p=0,002(0,002<0,05)$ yang berarti bahwa ada hubungan yang bermakna antara pengetahuan tentang karies gigi dengan jenis karies gigi pada mahasiswa.

\section{PEMBAHASAN}

Perilaku kesehatan gigi meliputi pengetahuan, sikap, dan tindakan yang berkaitan dengan konsep sehat dan sakit gigi serta upaya pencegahannya. Dalam konsep ini yang dimaksudkan dengan kesehatan gigi adalah gigi dan semua jaringan yang ada di dalam mulut, termasuk gusi. Seseorang memperoleh pengetahuan melalui penginderaan terhadap objek tertentu. Pengetahuan diperoleh sebagai akibat stimulus yang ditangkap pancaindera. Pengetahuan bisa diperoleh secara alami maupun secara terencana yaitu melalui proses pendidikan. ${ }^{1}$

Berdasarkan data pada tabel 1 menunjukkan bahwa responden dengan pengetahuan kategori "Baik" dengan jenis karies gigi kategori "Baik" sebanyak 29 responden $(38,7 \%)$, pengetahuan kategori "Baik" dengan jenis karies gigi kategori "Kurang Baik" sebanyak 35 responden (46,6\%), pengetahuan kategori "Kurang Baik" dengan jenis karies gigi kategori "Baik" sebanyak 11 responden (14,7\%). Dan pengetahuan kategori "Kurang Baik" dengan jenis karies gigi kategori "Kurang Baik" sebanyak 0 . Data di atas menunjukkan bahwa pengetahuan sangat mempengaruhi keadaan kesehatan gigi seseorang. Dimana dari 75 responden yang paling banyak adalah pengetahuan kategori "Baik" dengan jenis karies kategori "Kurang Baik" yaitu sebanyak 35 responden (46,6\%). Hasil ini menunjukkan bahwa pengetahuan mahasiswa sebagian besar berkategori baik, karena latar belakang pendidikan responden penelitian adalah mahasiswa Jurusan Keperawatan Gigi, sehingga materi atau informasi tentang karies gigi sebagian besar responden sudah mengetahuinya, baik yang didapat dari pembelajaran di kelas atau didapat dari informasi-informasi kesehatan melalui media kesehatan gigi dan mulut. Namun pada hasilnya 
diharapkan pengetahuan yang baik dapat mempengaruhi status kesehatan gigi dan mulutnya dalam hal ini karies gigi menjadi lebih baik, namun dari hasil penelitian yang didapat bahwa sebagian besar mahasiswa yang memiliki pengetahuan berkategori "Baik" memiliki jenis karies gigi yang berkategori "kurang Baik".

Pengetahuan yang hanya sekedar diketahui saja tanpa didasari dengan pendidikan yang memadai maka akan berpengaruh terhadap kemauan untuk menjaga dan memelihara kebersihan gigi dan mulutnya. Artinya bahwa semakin tinggi tingkat pendidikan seseorang maka semakin tinggi pula pengetahuan dan pemahaman yang dimiliki, sehingga memungkinkan seseorang mendapatkan pengetahuan atau informasi yang lebih, khususnya pengetahuan tentang karies gigi, sehingga pada akhirnya ilmu yang didapat bisa diaplikasikan dalam kehidupan sehari-hari dalam hal menjaga dan merawat giginya. Pengetahuan tentang karies gigi yang diketahui mahasiswa jika itu bukan hanya sekedar tahu, tapi di pahami dan diaplikasikan, pada akhirnya dapat mempengaruhi status kesehatan gigi dan mulutnya terlebih khusus dapat merawat gigi yang sudah karies dan masih bisa ditambal dengan perawatan penambalan sejak dini, sehingga dapat mengembalikan fungsi dan guna gigi sebagaimana mestinya, serta dapat menghindari kerusakan gigi yang lebih parah yang berujung pada tindakan pencabutan gigi yang dampaknya sangat besar terhadap kesehatan gigi dan mulut seseorang.

Pendidikan kesehatan berupaya agar masyarakat menyadari atau menguasai bagaimana cara memelihara kesehatan, menghindari, atau mencegah hal-hal yang merugikan kesehatan mereka dan kesehatan orang lain, kemana seharusnya mencari pengobatan jika mereka sakit dan sebagainya. ${ }^{2}$ Pendidikan kesehatan adalah upaya atau tindakan yang mempengaruhi orangorang untuk bertingkah laku yang baik terhadap kesehatan sehingga dapat meningkatkan kesadaran masyarakat akan kesehatan gigi dan mulut serta memberikan pengertian cara-cara memelihara kesehatan gigi dan mulut. ${ }^{9}$

Data pada tabel 5 dari hasil uji statistic menunjukkan bahwa Chi-Square hitung lebih besar dari Chi- Square tabel $(11,279>3,841)$ dengan menggunakan tingkat kepercayaan 0,05 (95\%) diperoleh nilai $\mathrm{p}=0,002(0,002<0,05)$ yang berarti bahwa ada hubungan yang bermakna antara pengetahuan tentang karies gigi dengan jenis karies gigi pada mahasiswa. Menurut Benyamin Bloom 1908 dalam (Notoatmodjo, 2003) pengetahuan (knowledge) merupakan hasil dari tahu, setelah orang melakukan pengindraan terhadap suatu objek yang tertentu. Tahu diartikan sebagai mengingat suatu materi yang telah dipelajari sebelumnya. Yang dapat diukur antara lain kemampuan untuk menyebutkan tentang apa yang dipelajari. Memahami diartikan sebagai sesuatu kemampuan untuk menjelaskan secara benar. Memahami dapat diukur antara lain melalui kemampuan untuk menjelaskan, menyebutkan contoh dan sebagainya terhadap objek yang dipelajari. Tingkat pendidikan dapat mempengaruhi pengetahuan seseorang, karena dengan semakin tinggi pendidikan seseorang diharapkan pengetahuannya semakin meningkat. Pengetahuan yang hanya sekedar diketahui saja tanpa didasari dengan pendidikan yang memadai maka akan berpengaruh terhadap kemauan untuk menjaga dan memelihara kebersihan gigi dan mulutnya. Artinya bahwa semakin tinggi tingkat pendidikan seseorang maka semakin tinggi pula pengetahuan dan pemahaman yang dimiliki, sehingga memungkinkan seseorang mendapatkan pengetahuan atau informasi yang lebih sehingga dapat mempengaruhi status kesehatan gigi dan mulutnya terlebih khusus pengetahuan tentang karies gigi. ${ }^{10}$

Hasil ini sejalan dengan penelitian dari Rahtyanti, dkk (2018) didapati bahwa pengetahuan kesehatan gigi dan mulut mahasiswa 
baru fakultas kedokteran gigi Universitas Jember, diperoleh persentase kategori baik sebesar 89,01\% sedangkan sisanya berada pada tingkat kategori sedang 10,09\%. Hal ini menunjukkan bahwa mahasiswa baru telah berhasil dalam memperoleh, mengingat dan memahami informasi dari apa yang dilihat dan didengar mengenai karies gigi serta telah mengetahui cara menjaga kebersihan gigi yang baik. ${ }^{6}$ Pendidikan sangat berhubungan erat dengan pengetahuan, terutama pengetahuan tentang kesehatan. Seseorang yang memiliki pendidikan tinggi diasumsikan memiliki pengetahuan yang baik. Semakin tinggi pendidikan formal seseorang maka semakin baik pengetahuan dan sikap tentang kesehatan yang mempengaruhi perilaku hidup sehat. Pendidikan kesehatan gigi dan mulut dapat menghasilkan perubahan atau peningkatan pengetahuan, sedangkan peningkatan pengetahuan belum tentu akan berpengaruh langsung terhadap status karies gigi. Pengetahuan yang baik belum tentu tindakan yang dilakukan baik pula. Hal tersebut karena pengetahuan sebatas perilaku tertutup, artinya masih terbatas dalam bentuk perhatian, perasaan dan persepsi.

Kesimpulan secara keseluruhan dari hasil penelitian hubungan pengetahuan tentang karies gigi dengan jenis karies gigi pada mahasiswa tingkat I dan II Jurusan Keperawatan Gigi Poltekkes Kemenkes Manado, didapati bahwa pengetahuan mahasiswa baik, akan tetapi sebagian besar mempunyai jenis karies gigi yang kurang baik, dengan tingkat keparahan atau jenis karies gigi yang berbeda-beda, dan pada tabel 4 menunjukkan jenis karies gigi terbanyak yang ada pada mahasiswa Jurusan Keperawatan Gigi yaitu jenis karies gigi profunda. Hal ini dapat disebabkan karena sebagian besar mahasiswa sebelumnya sudah mempunyai riwayat karies gigi. Karena proses untuk terjadinya karies gigi sudah berjalan lama dan memerlukan waktu yang lama. Pengetahuan tentang karies gigi adalah pengetahuan mahasiswa yang diketahui mengenai hal yang berhubungan dengan jenis karies gigi yang dialaminya. Semakin baiknya pengetahuan mahasiswa maka sangat berpengaruh terhadap perilaku dalam menjaga kebersihan gigi dan mulut khususnya untuk mengurangi penyakit karies gigi. Selanjutnya hal ini merupakan kekuatan pendorong yang memudahkan individu atau mahasiswa untuk berperilaku sehat dalam hal ini menjaga kebersihan gigi dan mulut sehingga dalam jangka pendek dapat terhindar dari masalah kesehatan gigi dan mulut seperti penyakit karies gigi. Dengan harapan jenis karies yang masih bisa ditambal segera ditambal, dan jika masih bisa dipertahankan untuk dilakukan perawatan bisa dilakukan tindakan perawatan, sehingga gigi bisa dipertahankan selama mungkin dalam mulut dan bisa mengembalikan fungsi dan guna gigi.

\section{KESIMPULAN}

Berdasarkan hasil penelitian yang telah di laksanakan pada mahasiswa Jurusan Keperawatan Gigi Poltekkes Kemenkes Manado, dan hasil data yang telah diolah dalam uji statistik maka diperoleh kategori pengetahuan baik sebanyak $85,3 \%$ dan jenis karies gigi kurang baik sebanyak $46,7 \%$ dengan jenis karies gigi terbanyak yaitu karies profunda 69,3\% kesimpulan bahwa terdapat hubungan antara pengetahuan tentang karies gigi dengan jenis karies gigi.

\section{SARAN}

Setelah melaksanakan penelitian dan membahas hasil penelitian ini, maka peneliti dapat memberikan saran yaitu agar mahasiswa Jurusan Keperawatan Gigi Poltekkes Kemenkes Manado dapat memperhatikan kesehatan gigi dan mulut, khususnya hal-hal yang berhubungan dengan karies gigi. Berdasarkan peneltian yang dilakukan, penelti menemukan karies terbanyak yang ada pada mahasiswa yaitu karies Profunda. Cara yang baik dalam memelihara kesehatan gigi dan mulut adalah dengan rajin menyikat gigi, mengurangi 
mengkonsumsi makanan manis dan yang mudah melekat, banyak mengkonsumsi buah-buahan yang dapat membantu membersihkan gigi yaitu buah-buahan yang berserat dan berair dan rajin kontrol gigi ke Puskesmas atau Rumah sakit terdekat untuk memeriksakan gigi dan sekaligus melakukan tindakan perawatan berupa penambalan untuk gigi yang masih bisa ditambal, sehingga kerusakannya tidak berlanjut dan disarankan mahasiswa untuk melakukan perawatan saluran akar di dokter gigi atau melakukan pencabutan untuk gigi karies profunda, sehingga tidak menimbulkan masalah yang berkelanjutan

\section{DAFTAR PUSTAKA.}

1. Budiharto. (2009). Metodologi Penelitian Kesehatan Dengan Contoh Bidang Ilmu Kesehatan Gigi. EGC, Jakarta.

2. Notoadmojo (2010). Promosi Kesehatan dan Ilmu Perilaku. Rineka Cipta, Jakarta.

3. Putri, M.H..,Herijulianti, E., dan Nurjanah, N, (2010). Ilmu Pencegahan Penyakit Jaringan Keras dan Jaringan Pendukung Gigi. EGC. Jakarta

4. Tarigan Rasinta. 2012, Karies Gigi, Hipocrates. Jakarta
5. Kementerian Kesehatan, RI (2018). Riset Kesehatan Dasar. Badan Penelitian dan Pembangunan Kesehatan RI. Jakarta

6. Rahtyanti, G.C.S., Hadnyanawati, H., \& Wulandari, E. (2018). Hubungan Pengetahuan Kesehatan Gigi dan Mulut dengan Karies Gigi pada Mahasiswa Baru Fakultas Kedokteran Gigi Universitas Jember TahunAkademik 2016/2017. E-Jurnal Pustaka Kesehatan, vol.6 no. 1

7. Riwidikdo, H. (2013). Statistik Kesehatan Dengan Aplikasi SPSS dalam Prosedur Penelitian. Rohima Press. Yogyakarta.

8. Sugiyono. (2009). Statistika Untuk Penelitian. Alfabeta.Bandung

9. Herijulianti, E., Indriani, T.S., Artini, S. (2001). Pendidikan Kesehatan gigi.EGC. Jakarta.

10. Notoatmodjo, S. (2003). Ilmu Kesehatan Masyarakat. PT Rineka Cipta,Jakarta. 